Article

\title{
Denying the Darkness: Exploring the Discourses of Neutralization of Bundy, Gacy, and Dahmer
}

\author{
Veronyka James \\ Department of Criminology and Criminal Justice, Shenandoah University, Winchester, VA 22601, USA; \\ vjames@su.edu
}

Received: 15 January 2019; Accepted: 26 May 2019; Published: 11 June 2019

\begin{abstract}
This exploratory study analyzed how three serial killers (i.e., Bundy, Gacy, and Dahmer) potentially rationalized and justified their murders by applying techniques of neutralization. This paper discusses how the use of these neutralizations also functions as a form of stigma management assisting in the maintenance of a positive presentation of self, thus mitigating responsibility for their crimes. This study conducted a content analysis of data comprised from interviews and case histories of these three serial killers. Based on these analyses, the impression is conveyed that these killers used neutralizations to manage their identities (i.e., present "normal" selves), mitigate responsibility for their actions, and minimize the stigma associated with being labeled a serial killer.
\end{abstract}

Keywords: neutralizations; serial murder; stigma management; symbolic interactionism

\section{Introduction}

Although serial murder fascinates, we actually know very little about these offenders [1]. Much of the research done on these offenders has used interviews to focus on their psychology and how their pathology manifests through behaviors during the commission of their crimes (i.e., profiling). This has then been used to determine commonalities between offenders in order to aid law enforcement investigations [2-9]. Few studies examine serial murder from a sociological or interactionist perspective [8,10-13]. Additionally, inquiries into how serial murderers socially construct their identities, present "normal" selves in the course of regular social interaction, and mitigate the stigma of the "serial killer" label have not been adequately addressed [1,10,12,14].

Research on serial murder still remains limited due to its rare occurrence and difficulty in obtaining access to offenders $[1,2,6,13,15-17]$. In addition to these obstacles and despite the proliferation of terms used to define multicide (i.e., mass murder, sexual/lust murder, spree murder, serial murder), there remains debate over the "true" definition of serial murder, which varies along a continuum of very broad to very specific $[1,3,4,6-9,11,13,15,18-27]$. Definitions vary with minimum number of victims (i.e., 2 to 4 ), varying cooling-off periods (i.e., time between murders), and various necessary motivations $[3,4,7-9,11,13,15,17-19,21-27]$. The disparities that exist over the way researchers define serial murder continues to complicate and impede research $[1,3,9,11,13,20,23-25]$.

In addition to the lack of definition, there is also "no singular theory that explains the phenomenon" [1] (p. 1). Additionally, there is little known about how killers can manage their identities through discourse and thus present positive self-images and minimize stigma through impression management $[1,12,14]$. It is through social interaction and accounting for behavior, particularly the use of verbal aligning actions (i.e., neutralizations), which allow individuals to maintain specific (and often positive) identities and self-definitions [28]. Viewed from a symbolic interactionist perspective, neutralizations are discursively furnished by offenders to mitigate responsibility, justify actions, construct and maintain a positive presentation of self, and manage identities, and are dependent 
on situated interaction drawing on prevailing cultural categories [10,14,28-39]. Narratives, and the neutralizations therein, are ways that individuals make sense of the social world, manage impressions of self, and socially construct identities. In the same way, serial killers may use neutralizations to manage their impressions of self without arousing the suspicions of others $[1,12,14]$.

Although there is a lack of theory that adequately addresses the etiology of serial murder, scholars have attempted to offer theoretical explanations for the phenomenon or apply different theoretical frameworks. S. Holmes et al. [11] proposed a new theory of serial murder, "Fractured Identity Syndrome" (FIS), which integrates Cooley's [40] idea of a "looking glass self" and Goffman's concept of "virtual social identity" [41]. S. Holmes et al. [11] argue that serial killers experience a social event, or a series of these events, that lead to a fracturing of their personality. This fracture causes the serial killer to present their virtual social identity (i.e., that of normal individual) to the outside, and their true, "fractured" social identity (i.e., murderer) is only known to them (and their victims in the process of killing) (see also [1]). These offenders learn how to manage and conceal the "stigma" of being a murderer by constructing this virtual social identity, which is continually managed in social encounters so that the offender appears normal [1,5,11,14,41,42]. With FIS, social event(s) cause a fracture of the personality, which makes the serial killer "learn" of their stigma (i.e., compulsion to kill), and then consciously conceal it from routine social interactions. The serial killer is constantly constructing and reconstructing an identity as "normal" and is in a constant state of maintaining this "normal" presentation of self during everyday social interaction. It is possible that neutralizations are used by these offenders in the construction and management of their virtual social identities allowing them to remain part of normative society while committing murder (with their fractured identities) [11,43]. Neutralizations may be the way in which these offenders are able to present normative selves within social interaction, compartmentalize their lives, and allow them to keep their fractured identities (i.e., murderer) hidden $[1,11,12,43]$.

Though neither study utilized the theoretical framework of neutralizations nor was from a sociological perspective, Henson and Olson [5] and Bartels and Parsons [42] both explored how serial killers ${ }^{1}$ manage their identities through discourse in order to present normal selves within social interaction $[5,42]$. Both studies found that the serial killers they examined managed their identities through discourse by either attempting to represent a normal or "sympathetic" self, admitting barriers to normalcy [5], or mitigating responsibility by saying that the actions were outside their control [42].

Through an examination of a fictional serial killer, Dexter Morgan, Force [14], examined how a serial killer can engage in impression management and manage multiple selves through social interaction. Force [14] argues that Dexter realizes that "normals" act a certain way and mimics these behaviors so as not to reveal his own stigma (i.e., desire to kill). Dexter is able to convincingly manipulate others' perceptions of him so that he appears "normal" and, thus, is constantly engaged in impression management [44], presentation of self, and managing his multiple selves. Force [14] illustrates with Dexter how he "performs" normativity and "passes" as a regular guy while continuing to be a serial killer.

It is theorized that three serial killers, Theodore Bundy, John Wayne Gacy, and Jeffrey Dahmer, used neutralization techniques [45] similarly to manage their identity through mitigating responsibility, minimizing stigma, presenting normal selves, and justifying their murders. Moreover, it is theorized that the use of neutralizations facilitates their construction of self, while also protecting their selves and defending against labeling and stigma $[1,5,12,14,42]$.

1 Henson and Olson [5] included "interviews with 13 notorious serial killers" (p. 347) in their study exploring how these offenders manage their stigmatized identities through discourse. These killers were: David Berkowitz (i.e., the Son of Sam), Kenneth Bianchi (i.e., one half of the Hillside Stranglers), Theodore Bundy, Jeffrey Dahmer, John Wayne Gacy, Jr., William Heirens (i.e., the Lipstick Killer), Henry Lee Lucas, James Paul, Dennis Rader (i.e., BTK), Richard Ramirez (i.e., the Night Stalker), Gery Leon Ridegway (i.e., the Green River Killer), Michael Ross, and Arthur Shawcross (i.e., the Genesee River Killer). Bartels and Parsons [42] examined the discourse of Dennis Rader (i.e., BTK). 


\section{Neutralization Theory}

Sykes and Matza [45] proposed neutralization techniques to explain how juvenile offenders can engage in delinquent behavior yet remain "committed to the dominant normative system" (p. 667). These techniques allow offenders to engage in deviant/illegal activities by providing a rationalization for these behaviors, allow offenders to protect their self-concept and deflect both self-blame and blame from others [1,12,30,45-53]. Maruna and Copes [30] suggest that the neutralizations used by offenders might not only be used to rationalize behavior, but also that these might be "implicated in the etiology of deviant behavior" (p. 222). Additionally, other researchers affirm this position, that neutralizations may be used not only after the fact to rationalize behavior but may actually influence and instigate future behavior [33,36,38,54-56].

Sykes and Matza [45] described five techniques ${ }^{2}$ used by offenders: denial of responsibility, denial of injury, denial of the victim, appeal to higher loyalties, and condemnation of the condemners; see also $[1,12,30,45-53]$. If the offender claims the behavior was outside his/her control or an accident (e.g., "I was late because my alarm didn't go off") this is denial of responsibility. Denial of injury is where the offender insists no harm was intended or there was no harm done despite the act being illegal (e.g., a juvenile steals a car to joyride, but returns it without damage). Denial of the victim is when the offender insists the victim does not deserve this status (i.e., harm was rightful retaliation), did something to instigate the offender or deserved what happened (i.e., it is really the victim's fault), or that there is no victim (i.e., absent or unknown victim). For example, the offender may claim that the victim hit them first, so they needed to retaliate which resulted in the victim being "beaten up". When the norms and values of a smaller subgroup take precedence over the offenders' attachment to dominant societal values, this is appeal to higher loyalties. Finally, with condemnation of the condemners, the offender rejects those who would reject him/her. The offender may claim that those denouncing them are secret deviants or hypocrites [1,30,45,46,48,52,53,57].

These neutralizations allow offenders to engage in criminal/deviant behavior while protecting their sense of self, avoid culpability, and minimize the stigma of being an "offender" $[45-48,53,55]$. As asserted by Maruna and Copes [30], "neutralizations are variously meant to protect a person from ... shame, guilt, remorse, self-awareness, loss of self-esteem, public labeling, and stigma" (p. 255). By using these to justify wrongdoing, offenders can protect themselves from blame and the associated stigma $[30,45,46,48,55]$. Neutralizations may also be the mechanism by which these offenders are able to "drift" in and out of criminality while maintaining commitments to conventional morals, norms, and behaviors (i.e., families, work, school); see also [1]. Neutralizations can be used by those either committed to normative society or those " ... who are in a state of drift ... partially committed to mainstream values but also committed to a certain lifestyle or set of behaviors that are labeled as deviant" [46] (p. 6, italics added). This could apply to serial killers who are committed to mainstream values since many are married, have kids, go to work, attend church, but who are also "committed to a certain lifestyle or set of behaviors that are labeled deviant" (i.e., serial murder) and thus allow them to drift between normative society and serial murder [12,45,46].

Researchers have also implicated narratives, and the neutralizations therein, as being central to sense making and construction of self. Narratives are how "... we create ourselves as consistent moral actors across settings and over time ... [and connect] ... the individual, the social, and the cultural" [58] (p. 24). Presser [54] argues that offender narratives have often been neglected yet should be utilized more to understand how offenders explain themselves and "... reconcile multiple selves" [54] (p. 180). Sandberg [38] suggests that narratives are used by offenders to present themselves in certain ways within social interaction and that these also allow for identity construction (and reconstruction) and

2 Researchers have expanded upon the initial techniques proposed by Sykes and Matza [45] (e.g., claim of entitlement, defense of necessity) [30,47-49,53]. However, it could be argued that their techniques are not any different than the original five proposed by Sykes and Matza [45] to be deemed different neutralizations. 
may also influence future behavior. Additionally, Maruna and Copes [30] advise that neutralizations should be considered from the perspective of sense making and identity construction. These are used by offenders, through the process of narration, to not only create and manage identities, but also to protect selves and defend against labeling [30]. Rather than merely allowing offenders to account for and justify behavior, these can be used as a form of impression management (i.e., technique of self-presentation and stigma management), construction of self, and sense making [30,38,54]. Narratives, and neutralizations, can also instigate future behavior " $\ldots$ because people tend to behave in ways that agree with the self-stories they have created about themselves" [59] (p. 70). In addition to facilitating future behavior, narratives are not static since "identity is a life-long project" [59] (p. 70). Identity is created, shaped, changed, recreated, and varies over time. Identity also varies based upon the social setting one finds oneself within, with whom one is interacting and how one is defining the situation [54,59].

Neutralization theory has been well researched and applied to a variety of different behaviors, including (but not limited to) cheating and underage drinking by college students [60,61], street "tagging" [62], "positive" deviance (i.e., high-achieving students) [63], white-collar crime [64-66], domestic violence [67-69], breastfeeding [70], animal rights activists [71], sexual violence [72-75], pedophilia [76,77], zoophilia [78], and killing in war [79]. However, there are limited studies examining murderers' use of neutralizations, particularly how serial murderers may use these not only to account for their crimes, but also manage their identities [1,12].

Analyzing the accounts of serial killers, and inherent within these, their neutralizations, may offer insight into how these offenders create their killer and non-killer identities [80], perceive the world, and (secretly) murder while also engaging in "normal" social interaction. Narratives, and the neutralizations therein, are ways that individuals make sense of the social world, manage impressions of self, and construct social identities. Since researchers assert that serial killers rely on the same social processes as non-offenders $[11,80]$, it is expected that serial killers, like non-offenders, use narratives, and the neutralizations therein, to create identities and present selves within social interaction. However, there remains a lack of inquiry into how serial murderers may use neutralizations to negotiate their identity, and socially construct their presentation of self.

\section{Methods}

This study utilized a content analysis of case histories and interviews from seven books written from interviews and/or firsthand experience with the offenders and three videos of interviews ${ }^{3}$ with the notorious serial murderers, Theodore Bundy, John Wayne Gacy, and Jeffrey Dahmer. It was deemed that this was the most appropriate method for this study since gaining access to these killers is impossible since Bundy and Gacy have been executed and Dahmer was killed in prison. Additionally, content analysis has been used by previous studies of neutralization theory and serial murder and has achieved results that could not have been produced using other methods [5,16,26,30,42,76,77].

The purpose of this study was to explore whether these serial killers used any of the five neutralization techniques proposed by Sykes and Matza [45]. Each technique was operationalized to determine for possible use by each serial killer in the texts and videos examined. For denial of responsibility, this was if the offender blamed the crime on a force outside themselves (e.g., drugs and/or alcohol) [12,45]. "Something expressed as beyond his control was also assessed as denial of responsibility, which included another personality present in the killer or possibly losing consciousness" [12] (p. 8). Statements were coded as denial of the victim if the killer asserted that the "injury is not wrong in light of the circumstances" [45] (p. 669). This would include if the killer stated or eluded to the victim

3 These sources are listed in the references, but are seven books written based on interviews or firsthand experience with the killers [81-88] and three videotaped interviews with the killers [89-91]. Two additional sources are books written about serial killers that included direct quotations from these killers or those who knew these individuals [19,22]. 
deserving what happened or if the killer twisted events to place " ... himself into the position of an avenger and the victim [was] transformed into a wrong-doer" [45] (p. 668).

The other techniques were operationalized in much the same way. If there was an assertation that no real harm was done, this was denial of injury [45]. Condemnation of the condemners would be if the killer blamed society or the police for their crime or asserted that those blaming them were doing so for spite, political gain, or that they were criminals themselves. And finally, "an offender using appeal to higher loyalties would state that the values of a subgroup took precedence over the social mandate not to kill" [12] (p. 9).

However, this method still has limitations. These results cannot be generalized to all serial murderers. Additionally, it is difficult to know whether the killers were only saying what they expected the interviewers wanted them to say (i.e., social desirability bias). Since serial murderers have been exposed to the same societal expectations as non-offenders, they are aware of normal societal expectations and thus their responses may be in line with these expectations. However, per Sandberg [38], it does not really matter whether the narratives provided are true or false, since these are used by offenders to present themselves in certain ways through social interaction. Thus, the veracity of the narratives is less important than how offenders use these to manage identities and stigma and present themselves to others within social interaction $[38,58]$.

This method was used to explore whether these offenders offered neutralizations for their crimes. Also explored is how these offenders used neutralizations to construct identities, present positive selves, and protect their self-concept from labeling and stigma. Despite the limitations, a content analysis was considered the most appropriate method for this inquiry. Sometimes it is necessary to use imperfect sources of information to advance knowledge in certain areas [16].

\section{Theodore (Ted) Robert Bundy}

Ted Bundy was an American serial killer born in Vermont in 1946. He killed females between 1974 and 1978 in Washington, Utah, Colorado, and Florida [13]. He confessed to killing thirty women, but is suspected of killing many more, possibly over 100 [22]. During his last arrest, when he was asked by a detective about whether he had committed thirty-six murders, "Ted had reportedly replied, 'Add one digit to that and you'll have it'" [81] (p. 380). Ted Bundy was executed on 24 January 1989, in Starke, Florida [22].

Bundy produced a façade of great sincerity and a social veneer, which hid his true self as a murderer and he used this within social interaction. Many described Bundy as attractive, normal, educated, "nice person", "mild mannered law student", charming, "perfect son", "perfect student", and trustworthy $[22,27,81,89]$. But these were the virtual identities he managed and presented to everyone except his victims. According to Hickey [22], “ ... his quest for identity served as a catalyst for constantly presenting himself, especially in physical disguise, to be somebody else ... Ted created a series of social fronts and disguises to help him blend into the "right groups'" (p. 186, italics added). To his victims, he was a sadistic murderer. According to Bundy, "I became an expert at projecting something very different ... a huge part of my life was hidden from everyone-a secret, as it were" [82] (p. 17). Bundy was adept at hiding his "true" self as a murderer from everyone in his life, but was a master at manipulating others to only see his virtual identities of law student, boyfriend, son, and "nice, normal guy" [11,81-83,89].

Although he initially denied the extent of his crimes when caught, Bundy later confessed to several of the murders of which he was suspected. Yet, even in many, though not all, his confessions, he often talked in the third person when discussing these crimes, still attempting to manipulate his presentation of self and mitigate any stigma attached. According to Keppel [83] (p. xi), " ... allowing subjects to speak in the third person, gives them the chance to talk directly about themselves without the stigma of confession." By talking in the third person, referring to himself as "this individual", Bundy was able to speak about himself without any possible legal repercussions or without the stigma associated with committing the crimes for which he was accused [82,89]. There were some of his 
confessions, just before his execution, where he did speak in the first person detailing his crimes mostly as a failed manipulative plea to stay his execution $[82,83]$.

In his discussions of his crimes, whether in third or first person, Bundy was "a consummate gamesman" [82] (p. 3). Described as a "master craftsman" [22] (p. 188), he often tried to manipulate the interviews, the perceptions of others, and provide a specific presentation of self during these interactions. As Bundy said:

"I had a guy sit down and tell me stories. I knew he was telling me stories. And yet, I also knew that, essentially, he'd done what they said he did, but he had a need to tell it a different way so he looked different, he looked better. In his own mind, okay? He wasn't a savage, lust-filled killer, but he was this guy who just- - he just got mad. The bitch made him mad. So it's very curious how guys-some men who committed a series of murders over the years, in their own mind, will rewrite history to satisfy their needs. And they will lie" [83] (p. 337).

Although he made it appear that he was speaking about someone else, he most likely was speaking about himself, but framing it as "someone else" similar to how he framed speaking about his crimes as those "this individual" or "someone like that" would have done [82,89]. During these various discussions, Bundy appeared to use three of the five neutralizations (i.e., denial of responsibility, denial of the victim, and condemnation of the condemners) and also tried to make himself "look better", "rewrite history", present himself in a certain way (i.e., "normal, a Boy Scout" [89], and mitigate stigma.

\subsection{Denial of Responsibility}

Bundy appeared to use denial of responsibility in his discussion of his crimes to deny any blame that could be attributed to him for these actions, and mitigate stigma associated. Indications that Bundy used denial of responsibility to deny blame and mitigate stigma include his attributing his crimes to the influence of alcohol/drugs and pornography/detective magazines. For example, in discussing how someone could commit the crimes of which he was suspected he said, " ... if you take into account the effect of alcohol. It's important. It's very important as a trigger. When this person drank a good deal, his inhibitions were significantly diminished" [82] (p. 71, original italics). Bundy stated that alcohol lowered inhibitions, which makes it possible for "someone" to engage in these behaviors (i.e., murder). He also stated "... and I was drunk" [83] (p. 425) when discussing the murder of Georgann Hawkins and at another point, discussing victim Donna Manson, he stated, "as I sometimes had a bottle of wine in the car and was just, among other things, extremely drunk" [83] (p. 430). Although not explicitly saying so, Bundy alludes to the fact that he should not be held as accountable since he was drunk. By blaming something else, Bundy is mitigating full responsibility for his actions, thereby maintaining a more "normal" presentation of self. He is suggesting that if he had not been "extremely drunk" then maybe he would not have committed these crimes (however, in all likelihood he still would have done so even if he had been sober). "Frequently a murderer will try to assign blame for his deeds on drinking or drugs. While intoxicants can certainly relieve people of inhibitions, they are almost never the "cause' of murderous actions" [84] (p. 146). By blaming something else, it is not really his fault and thus he should be not held as accountable for these actions.

Bundy also, in one of his last interviews, indicated that not only alcohol, but also pornography was a contributing factor for his crimes $[81,89]$. He said:

"I encountered ... soft-core pornography ... but as young boys do we explored ... and from time to time we would come across pornographic books of a more explicit nature ... those of us who are, who have been so much influenced by violence in the media, in particular pornographic violence are not some kind of inherent monsters. We are your sons, and we are your husbands". [90]

Bundy, when asked what his life would have been like without pornography, also stated: 
"... it would have been far better ... for me ... it would have been a lot better for me and lots of other people ... lots of other innocent people, victims and families ... a life that would not have involved ... this kind of violence I have been, I have committed". [90]

Again, Bundy alludes to the fact that it was the pornography that "caused" him to do the things he did. If he had never discovered "pornographic violence", then maybe he would not have committed the crimes he did and thus again should not be as stigmatized. By saying that others, "your sons [and] your husbands", also consume these images, Bundy suggests that he should not be stigmatized since others in society are also consuming this media. As stated by Rule [82] (p. 611, original italics), "... once again, [he places] the onus of his crimes, not on himself, but on us". He is thus mitigating his responsibility for his crimes in blaming his alcohol and pornography consumption and also suggests that society should be blamed for allowing him to have indulged in these vices.

\subsection{Denial of the Victim}

Bundy also appeared to use denial of the victim when discussing his crimes. Again, often he did not speak in the first person, but rather how "someone" would think of the victims, choose specific victims or justify murdering others. Most likely these were how he thought of his victims and justified his crimes in his mind, even though he talked about it in a more abstract way. For example, Bundy stated, "outside of the fact they've made themselves available in some, perhaps, unconscious way. What we're talking about here is just opportunity, as opposed to more discreet factors that would be exhibited by that person" [82] (p. 82). Bundy is putting the responsibility of being a victim on the victims themselves saying that they made themselves available to be victimized. Even if it was unconscious, Bundy is still placing the responsibility of being victimized on the victim rather than on him, the perpetrator.

Bundy also stated:

" ... there might be some mass murderers who might say, 'Well she or he would have hurt me if I hadn't hurt them.' And they might also say, 'Well, there's so many people, they won't be missed.' So what's one less?... and I'd say ... the victim was luring them or trying to arouse them, uh, in some way. They deserved it, you know, or, uh, all sorts of things like that". [82] (p. 188, original italics)

Again, Bundy blamed the victim for what befell them, rather than accepting responsibility for the murders. Although again speaking of others, it is reasonable to assume that Bundy felt the same way in regards to his victims since, like in other interviews, he often talked about "this individual" or "some mass murderers" as a way to speak about himself without the consequences associated (i.e., legal consequences, damage to his persona, stigma). He, most likely, thought "they deserved it". As a result, he again is deflecting blame and stigma from himself and placing it on the victims. If the victim had not aroused him, or interested him, or did whatever he felt the victim did to "deserve" the victimization, maybe nothing would have happened (though again, in all likelihood the victimization would have still occurred even if the victim had done nothing).

\subsection{Condemnation of the Condemners}

The final neutralization Bundy appeared to use was condemnation of the condemners. Bundy stated:

"And I poke fun at the police because they're damn ... not incompetent ... but they're so ineffective. They may be incompetent, too, but by and large, they're just not using their heads ... Since they are the ones who are challenging me and accusing me, I've every right to criticize them". [82] (p. 164)

Although not explicitly saying they are hypocrites or secret deviants, Bundy criticized the police, called them incompetent, and often made fun of them. He also spoke of the evidence against him being 
fabricated, or that they were using his case for publicity [81]. In this way, he was condemning those who were condemning him by saying that they were insincere, incompetent, corrupt, or ineffective and by doing so, he is again shifting blame from himself and placing it on others. If they had made a mistake (because they are incompetent), then maybe he really is not to blame for these crimes. As he stated, " 'if anyone considers me a monster, that's just something they'll have to confront in themselves'" [81] (p. 544). He, again, is not at fault; it is others who are at fault.

Although not a neutralization provided, Bundy also referred various times to constructing identities and playing different roles in different situations. At one time in court, he stated, "'I'm disguised as an attorney today"" [81] (p. 416). He also intimated to how someone could construct these various identities (i.e., normal in most social situations and killer with victims). He stated:“ . . it's a critical balance, not a delicate balance. It became almost like acting a role. It wasn't difficult. The more an actor acts in a role, the better he becomes at it, the more he is apt to feel comfortable in it, to be able to do things spontaneously. And get better, as it were, in his role". [82] (p. 109)

He knew he constructed various identities (e.g., law student in school, loving boyfriend with his girlfriend Liz, callous killer with victims), and understood how he needed to manage these and perform in certain ways to present theses various selves within the social interaction in which he found himself. Additionally, by using the neutralizations he relied upon, this may have assisted in his ability to construct these various virtual social identities and manage his presentation of self in different social interactions.

\section{Jeffrey Lionel Dahmer}

Jeffrey Dahmer, another American serial killer, was born in 1960 in Wisconsin. He dismembered and murdered 17 young men and boys [22] between 1978 and 1991. He not only dismembered his victims, but also engaged in necrophilia and cannibalism. Unlike Bundy, Dahmer did confess to his crimes upon apprehension, never denied committing the crimes of which he was accused, and "he blamed no one or no thing for his crimes, including his parents, society, or pornography" [22] (p. 143). He was convicted and received 15 consecutive life sentences. However, in 1994, he was beaten to death by a fellow inmate [13].

Despite not blaming "anyone or anything for his crimes", Dahmer still utilized neutralizations when discussing his crimes to minimize the stigma associated with his behaviors rather than negate any responsibility. These neutralizations allowed Dahmer to manage and present a positive self-image. Similar to how other violent offenders used neutralizations to present positive self-images, Dahmer, by using these techniques when discussing his crimes, is not that bad a person and is able to attempt to maintain a positive self-image and lessen the associated stigma $[35,36,39,54]$. Techniques of neutralization not only allow for one to deny responsibility for one's actions, but also allow one to protect themselves from shame, public labeling, and stigma [30]. Dahmer thus used neutralizations in this way despite taking responsibility for his crimes.

Similar to Bundy, Dahmer was adept at managing different identities and presenting different selves during social interaction. When caught and arrested, many people were shocked to learn of the crimes of which Dahmer was accused [85]. Although described as a "loner", people also described him as a "good neighbor", and "unassuming", though at the same time he was killing, dismembering, and cannibalizing his victims. There was even an incident where one of his victims, after being sexually assaulted, escaped from Dahmer's apartment. However, when police arrived, Dahmer was able to convince them that it was merely a lover's quarrel $[19,84,85]$. The police even went back to Dahmer's apartment with the boy where "they were bamboozled by the courteous Dr. Jekyll side of Jeffrey Dahmer's personality" [85] (p. 76). Soon after the police left, Dahmer killed the boy. "Dahmer was very persuasive, intelligent enough to be able to convince the police that nothing beyond the ordinary was happening at his residence or in his relationship to the young man" [84] (p. 133). Dahmer was 
able to successfully present the image of "normal guy" just having a disagreement with his lover to the police, rather than serial killer trying to catch his escaped victim. As stated by Hickey [22] "to most his victims he seemed like a very average person wanting to be sociable" (p. 142), and to many others he presented the image of an average, albeit odd, person.

\subsection{Denial of the Victim}

Although Dahmer did confess and take responsibility for his crimes, he still, like Bundy, used denial of the victim to shift the focus from himself to his victims. Dahmer stated "'the guy wanted to leave and I didn't want him to leave'" [85] (p. 39). If the guy had not wanted to leave Dahmer, then he would not have killed the victim to keep him. Similar to Bundy, Dahmer is putting the responsibility for the murder on the victim. It was the victim's actions (i.e., trying to leave) that instigated the murder. By shifting the blame for the victimization onto the victim, he then lessens the stigma associated since it is not wholly his fault what happened; the victim shares responsibility for their victimization. Since denial of the victim is where the offender claims that the "injury is not wrong in light of the circumstances ... [and] is a form of rightful retaliation or punishment" and where the offender "moves himself into the position of an avenger and the victim is transformed into a wrong-doer" [45] (p. 668), Dahmer places the responsibility on the victim since the victim wanted to leave. The murder was because the victim tried to leave, thus Dahmer is rationalizing his actions as a form of "rightful retaliation" for the victim's decision to leave. If the victim had stayed, then there would have been no reason for Dahmer to "punish" him for this desire to leave.

In one of his interviews, Dahmer stated:

"It was totally unplanned, it was a total surprise to me that it had happened ... Yeah [that was just a chain of events]. We got undressed. Just laid around. Body rubs ... And I-uh-found him attractive enough that I wanted to keep him. So I just made him the drink, and that was that". [84] (p. 153)

Although not explicitly saying the victim did something to instigate the murder, Dahmer is redefining the situation to transform the victim into a "wrong-doer" [45] (p. 668). Similar to how rapists deny the victim by "presenting the victim in a light that made her appear culpable, regardless of their own actions" [75] (p. 534), so too does Dahmer try to present his victims in a way that makes them appear culpable. Scully and Marolla [75] found that some rapists placed the onus of the assault on their victims by saying that the victim was "seductively attired" or "dressed in tight black clothes and without a bra" (pp. 536-537), thus the victim "deserved" what happened due to their provocative dress. In the same way, Dahmer places the fault on his victim because he found him attractive and makes him a "legitimate" victim who deserves his fate $[45,75]$. Dahmer had not planned to kill anyone. The sequence of events was "unplanned" but then Dahmer found him "attractive enough" and wanted to "keep him", so the murder occurred. If the victim had not been attractive enough, then Dahmer would not have felt the desire to keep him and thus would not have killed him. Thus, despite having taken responsibility for these crimes, Dahmer is still shifting blame from himself to his victim and minimizing any stigma, labeling or shame that would be attached to his actions. "... In the mind of the killer the event seems at least partially precipitated by the actions of the victim - that the death is at least partially the fault of the victim" [84] (p. 153).

\subsection{Denial of Responsibility}

Dahmer also utilized denial of responsibility to reduce stigma and present a positive self in his interviews. Although Dahmer did drink frequently $[19,84,85,91]$, he, unlike Bundy, did not explicitly blame alcohol for his murders. However, Dahmer did deny responsibility by saying he passed out and awoke to a dead body. This passing out could have been a result of heavy, frequent drinking or could have been the way Dahmer chose to deflect blame, minimize associated stigma, and maintain a positive presentation of self. Discussing one of his early murders, Dahmer stated, "apparently I'd 
beaten him to death ... I don't recall doing that ... A total black-out" [85] (p. 123, original italics). By not remembering the event, he attempts to absolve himself of responsibility for the action. He is suggesting that "I should not be held responsible for something I don't remember".

In a different interview, discussing the same murder, Dahmer again relies on the justification of "passing out" to deny responsibility for what had happened. Dahmer stated:

“ ... and, uh, was just goin' spend the night with him. When I woke up in the morning, uh, my forearms were bruised, and his chest was bruised and blood was coming out of his mouth, he was hanging over the side of the bed and I, uh, have no memory of beating him to death, but I must've ... I had no intention of hurting him at all". [91]

Dahmer again is suggesting that he should not be held (as) responsible for what happened since he could not remember hurting/killing his victim. He lost consciousness and thus does not remember his actions, and as a result, should not be held accountable. Since he does not remember what happened, he is attempting to maintain a positive presentation of self, and alleviate any potential stigma associated with his actions. Dahmer even states that he had no intention of hurting his victim. However, despite no intention of harm, his victim ended up dead even though Dahmer could not remember committing this crime. By stating he had "no intention of harm", Dahmer is attempting to maintain a positive self-image, since despite committing murder he had not intended to do so. It "just happened" as a result of his blacking out and he awoke to a dead body. He insinuates that this could, potentially, happen to anyone and as a result he should not be stigmatized since he merely woke up to a dead body without any recollection of the crime occurring. However, it is unlikely that this would or could happen to others, since Dahmer went on to kill (and remember killing) 15 more victims. This implies that he did not "just wake up" to a dead body but killed this victim like the others and either cannot remember the act or merely said he could not remember to mitigate the stigma and maintain a positive identity.

\section{John Wayne Gacy}

John Wayne Gacy, an American serial killer, was born in 1942 in Illinois. Gacy killed 33 young men and boys between 1972 and 1978, burying the majority in the crawl space beneath his house, though once he ran out of space, he also disposed of bodies in the Des Plaines River [13,22,84]. Gacy did initially confess to several of the murders, but later recanted these confessions [22]. Even though he plead not guilty by reason of insanity, he was convicted and sentenced to death, and executed in 1994 by lethal injection [13].

Similar to Bundy and Dahmer, Gacy did not "look" like a serial killer. Those who knew him described Gacy as a "likeable man", gregarious, smart, and "funny" [19,86]. One said, "The John Gacy I'm reading about in the newspapers is not the same John Gacy I knew" [19] (p. 72). Even though visitors to his house sometimes complained about a foul odor (due to the bodies in his crawl space), Gacy was able to explain it away by blaming it on dampness creating the odor [22]. Gacy was able to successfully present a self of successful businessman, "nice guy", quiet and kind, and a pillar of the community even going as far as volunteering as "Pogo the Clown" for "children's parties and at hospitals" [22] (p. 346). Gacy stated, "Where the hell could I have found time? I was working 16 hours a day, and the rest of my time was devoted to the community, charity affairs, and helping you people" [22] (p. 347). However, "the deadly is always there, but the murderer is frequently successful in hiding it from the outside world" [86] (p. 242).

Gacy also appeared to use neutralizations to rationalize his crimes. "Gacy seemed to rationalize everything he did ... if his actions could be seen in a negative light, he would twist the truth so that he would be viewed as having committed no wrongdoing" [19] (p. 83). Even after his arrest and conviction, he tried to portray himself as a good guy, ethical, and a hard-working family man. Gacy insinuated the use of denial of the victim and denial of responsibility when discussing his crimes to attempt to maintain this portrayal of "good guy", mitigate responsibility and minimize any potential stigmatization. 


\subsection{Denial of Responsibility}

Similar to Dahmer, Gacy claimed that there were times where he "blacked out" or could not fully remember the sequence of events that led to the victim's demise. In discussing one of his murders, Gacy stated:

"Now, this is where it gets a little foggy. I'm not exactly sure how all this happened, but I must have strangled him ... he was laying on the floor when I woke up. He was blue in the face". [87] (p. 140)

Gacy attempted to deflect blame and responsibility for his murder by saying he is not sure what had happened, only that he found the body upon waking up. Though he does say that he "must have strangled him", Gacy still attempted to deflect responsibility by saying he does not remember exactly what happened. Since he does not remember what happened, he, like Dahmer, should not be held wholly responsible for it.

In addition to blaming blackouts, Gacy also blamed another personality, Jack Hanley ${ }^{4}$, for these crimes occurring $[86,87]$. Gacy sometimes used this name and persona when cruising for victims. Once caught, Gacy also "was telling many of them [cops and prosecutors] that John Gacy did not commit these grotesque acts-Jack Hanley did" [87] (p. 215). Gacy was able to present this persona when cruising for male sexual partners and victims, yet he was John Gacy with friends, co-workers, and family. He was able to create and manage two different identities depending on the social interaction in which he found himself. Additionally, after being caught, he tried to claim he suffered from multiple personality disorder and that his other personality, Jack, was the one who killed [86]. This is not to say that by having a mental illness or pleading insanity one uses neutralization techniques. However, Gacy used the excuse of having another personality as a way to assert denial of responsibility (i.e., something outside of his control caused him to act this way, thus he should not be held responsible). The majority of serial murderers do not have multiple personality disorders, and although they often try to plead guilty by reason of insanity (e.g., Gacy, Dahmer, Bianchi, etc.), this plea is almost never successful. There was no evidence to suggest Gacy actually suffered from multiple personality disorder, but rather used this merely as an excuse so that he would not be held as accountable (or accountable at all [i.e., acquitted]) for his crimes. He stated that he was not aware of what Jack did and Jack was not aware of what John did. "'There are four Johns ... I don't know all of them.' One of the four, Gacy explained later was called 'Jack'. The body in the crawlspace? You'd have to ask Jack how they died" [88] (p. 5). By placing the blame on his other personality, he is again deflecting culpability for his actions. Since he was not aware of what "Jack" did, Gacy should not be held responsible. Similar to "blacking out", since Gacy is unaware of what happened when "Jack" took over, he should be absolved of responsibility and not be blamed for these murders. In doing so, Gacy was also able to maintain his view of himself as "good guy", since "Jack" was the "bad one". Gacy stated that Jack was the" .. "Bad $\mathrm{Me}^{\prime}$ [who] had committed the murders. His denial of the 'Bad Me' allowed the belief in himself to be fundamentally good" [86] (p. 246). By trying to blame the murders on his alternate personality, he attempted to maintain a positive self-image and his "good guy" identity, both to himself and others, and minimize stigma. The stigma of mental illness (i.e., multiple personality disorder) is lesser than the stigma of serial murderer [5].

Gacy also claimed "the killings were the work of his employees in the construction business, who, he said, shared the house with him" [84] (p. 74). He stated that several employees of his construction business had keys and access to the house and these people could come and go as they pleased $[22,84,86]$. Although Gacy did state he should be responsible for covering up these crimes, he often would state that he should not be held fully responsible because he was not the one who committed the murders. Others, with access to the house, were the ones sexually assaulting and killing the victims and placing 
them in the crawl space, and although Gacy "knew" about these crimes, he did not participate in their commission. Gacy stated, " ... [what] I should be charged with is complicity in the cover-up ... 'cause I was at the house ... I believe he was strangled ... by Baker" [84] (pp. 84-85). In this way, Gacy again is trying to deflect blame, but still appear as though he is taking some responsibility. Gacy can remain the "good guy" since he is not completely denying all responsibility, he is only denying responsibility in the commission of the crime but is taking responsibility for being an accomplice and being complacent in covering these up. However, it is difficult to believe, even if he did not, as he affirmed, commit the murders, that he had no knowledge of the bodies decomposing in his crawl space, since even those who visited his house complained of a foul odor.

Using these neutralizations and explanations were all an attempt to deflect blame from himself, create doubt that he was the sole perpetrator and thus sustain a positive presentation of self and lessen any stigma. Since he had no knowledge, or had some, but not complete knowledge of these crimes, again he should not be held fully responsible. At the least he should only be held responsible for complicity, but not responsible for these crimes since he did not commit them; others who had access to his house did.

\subsection{Denial of the Victim}

Gacy also frequently used denial of the victim in discussing his crimes. Similar to Bundy, he would speak about how the victims in some way brought the victimization upon themselves. He referred to his victims as "hustlers, greedy little liars and hustlers" [87] (p. 141). In one discussion, he said that he would go down to Bughouse Square (where the male prostitutes offered themselves for money), would pick up a prostitute who would then try to extort him, either for more money, or to keep the secret of him picking them up, and as a result he had "to get rid of" him [87] (p. 141). Gacy stated:

"Extortion, plain and simple they would see that I was successful and they would figure out that I couldn't let anyone know that I was bisexual. And then they would threaten to tell the neighbors. They should have kept their fucking mouths shut. They didn't know who they were dealing with". [87] (p. 141)

If the victim had not tried to extort Gacy or blackmail him, then he would not have had to be "dealt with". It is possible that the extortion never occurred and Gacy only used it as a way to rationalize his murders. He did not want his identity of successful, heterosexual, businessman, to be shattered by the information that he picked up male prostitutes, so he used this as a way to rationalize murdering these victims.

Even without using the excuse of being extorted, Gacy viewed the victims negatively. He referred to them as "scum, weak, stupid, degraded" [88] (p. 153). "He explained the murders as ridding society of its 'bad element'" [13] (p. 51). By viewing the victims in this way, he also assigns blame for their victimization. If they had not been "scum", "hustlers", "the bad element", then maybe they would not have become victims. As a result, it is not his fault they were victimized, but rather their fault because of their social status and the behaviors in which they engaged. "Ultimately, he came to justify murder as socially acceptable because of the degraded nature of his victims (human trash) and a disordered belief that his murderous behavior was of assistance to society" [19] (p. 81). Not only did he rationalize his behavior by viewing the victims as instigating their own victimization, but also by believing that he performed a service to society by ridding it of these individuals. Gacy even went as far as to blame the parents of his victims. "He blamed some of the parents for the deaths of their own children because their sons are prostitutes" [22] (p. 347). It was not enough to blame the victims themselves for their victimization, but he extended this to include the parents of his victims for being responsible for their children becoming prostitutes and thus becoming victims.

In addition to suggesting the victims were responsible for their own victimization due to their status within society, Gacy also stated, for one of his murders, that he acted in self-defense. Gacy stated: 
“... we fall asleep. Went to sleep ... Then I wake up, and he has a knife. He's coming at me with a knife! ... He tried to stab me. He fuckin' tried to stab me! ... So, I grabbed him, grabbed his wrist and wrestled him, pushed him off me ... He didn't think I was going to wake up. I was lucky I did cuz I'd be dead otherwise ... There was no reason for it. He was some kind of sleazy, greedy hustler. I wrestled him out of that room ... We fought and wrestled out of the room .... and ... that's when I got stabbed, cuz that's what made me mad, cuz that's when I got the knife ... took the knife from him and stabbed the fucker in his chest four or five times ... I was bleeding on him, and he was bleeding ... The son of bitch was going to get blood all over my rug!". [87] (pp. 132-133)

Gacy still refers to the victim as a "hustler", but also states that he stabbed him in self-defense. The victim was originally coming at Gacy with a knife, and in his recounting even stabbed him, before Gacy was able to wrestle the knife away and end up stabbing the victim "four or five times" ultimately killing him. Self-defense is a socially and legally justifiable excuse for killing someone. By claiming self-defense, Gacy is again attempting to deflect blame from himself and place it onto the victim for his actions. If the victim had never picked up the knife, stabbed and tried to kill Gacy, then Gacy would not have had to stab and kill him in self-defense. However, it is debatable whether this was the unbiased sequence of events ${ }^{5}$. More likely, Gacy killed this victim and only recounted the "story" of self-defense to present himself in a positive light, maintain his "good guy" identity, and minimize any stigma associated with killing someone. Since he acted in self-defense, and this is an acceptable reason for perpetrating homicide, then, again, he should not be held accountable, should not be stigmatized, and, moreover, should be commended for saving his own life.

\section{Conclusions}

It appears that these three notorious serial murderers, Ted Bundy, Jeffrey Dahmer, and John Wayne Gacy utilized at least some of these techniques of neutralizations [45] when recounting their crimes to rationalize their behaviors. Despite their "true" identity of serial killer being exposed due to arrest, trial and conviction, these killers still accounted for their crimes using neutralizations in an attempt to retain control over the "narrative" and maintain "morally decent selves". Researchers [32,34-36,38,54,75] found that despite being arrested and convicted of violent crimes (i.e., assault, rape, attempted murder), offenders still attempted to present "morally decent selves" when recounting their crimes. Similarly, neutralizations may facilitate the creation and maintenance of these "decent selves" by, at least these three, serial killers despite details of their crimes being known, and thus, also, their "actual social identities". By using these techniques, these murderers are able to "neutralize deviance in the past for the sake of nondeviant self-presentation today" [35] (p. 88).

By offering these neutralizations, these offenders attempt to make themselves and their behavior more tolerable, which is particularly the case when using denial of the victim. By stating the victim acted in some way to instigate their own victimization or that the murderer acted in self-defense, this allows the murderer to recast themselves as victim rather than perpetrator. They can mitigate responsibility for their actions, maintain their positive presentation of self, and minimize the stigma of being a "multiple murderer".

Although this research cannot be generalized to other serial murderers, it does provide potential insight into how these offenders view themselves, their crimes, retain control over the narrative of their crimes and lives [5,33-36,42], and account for their behavior, as well as the use of techniques of neutralization. This research also supports previous research examining how offenders, and

5 This story was recounted in various ways by Gacy. In one, the victim stabbed Gacy and was then killed in self-defense [85]. In another, Gacy claimed the victim was approaching him with the knife, slipped and fell on it, killing himself by accident [92]. In other recounts, Gacy overreacted thinking the victim was going to attack him with the knife so he stabbed him to death, though in reality, the victim had been making breakfast for two and still had the knife in his hand [92]. 
serial murderers, rely upon the social processes and cultural categories to manage identities, present normal selves through social performance and engage in stigma management $[1,5,12,32,34-36,38,42,54]$. Additionally, an implication of this research is that not only do "minor" offenders (e.g., shoplifters) use neutralizations when discussing their crimes to minimize stigma, present positive selves, and lessen responsibility assigned for their actions, but so do serial killers. As a result, techniques of neutralization could be viewed as a universal theory of crime [12]. Moreover, these techniques might not only be used after-the-fact by killers to reduce shame, protect self-image, labeling and/or stigma associated with their crimes, but could be how an offender is able to do the same before or during the commission of a crime [1]. These techniques may, additionally, assist these offenders in moving from single murderer to multiple murderer, thus instigating future criminal behavior $[33,36,38,54-56]$.

Moreover, the use of neutralizations could be the way these serial murderers were able to commit their crimes while maintaining "normal lives" (e.g., be in relationships, hold down jobs, have friends) [1,12]. By utilizing these techniques, these killers protected their self-perceptions (to themselves and others), and could view themselves as "good people", "nice guys", "mild-mannered", friend, neighbor, boyfriend, husband, but yet still engage in serial murder. As stated by Bundy, "I'm just a normal individual" [89]. The use of these techniques of neutralization could be how he (and Dahmer and Gacy and potentially other serial killers) could view themselves and present themselves to others in this way (despite knowledge of their crimes being known) [1,12].

Future research should further explore whether, and how, these neutralizations allow serial murderers to drift between conventional society and murder. Future research should also, if possible, examine serial murderers who are still alive and incarcerated. Additionally, research should examine whether the use of neutralizations allows for future crimes (i.e., are used before-the-fact), or only help to manage and present selves, minimize stigma and mitigate responsibility after-the-fact.

Funding: This research received no external funding.

Conflicts of Interest: The author declares no conflict of interest.

\section{References}

1. Pettigrew, M. Confessions of a serial killer: A neutralisation analysis. Homicide Stud. 2018. [CrossRef]

2. Chan, H.C.; Heide, K.M.; Beauregard, E. What propels sexual murderers: A proposed integrated theory of social learning and routine activities theories. Int. J. Offender Ther. 2011, 55, 228-250. [CrossRef] [PubMed]

3. Ferguson, C.J.; White, D.E.; Cherry, S.; Lorenz, S.M.; Bhimani, Z. Defining and classifying serial murder in the context of perpetrator motivation. J. Crim. Just. 2003, 31, 287-292. [CrossRef]

4. Federal Bureau of Investigation. Serial Murder: Multi-Disciplinary Perspectives for Investigators; National Center for the Analysis of Violent Crime: Washington, DC, USA, 2008. Available online: http://www.fbi.gov/ stats-services/publications/serial-murder/serial-murder-july-2008-pdf (accessed on 20 March 2012).

5. Henson, J.R.; Olson, L.N. The monster within: How male serial killers discursively manage their stigmatized identities. Commun. Q. 2010, 58,341-364. [CrossRef]

6. Hinch, R.; Hepburn, C. Researching serial murder: Methodological and definitional problems. Electron. J. Sociol. 1998, 3, 1-11. Available online: http://sociology.org/content/vol003.002/hinch.html (accessed on 20 March 2012).

7. O'Reilly-Fleming, T. Serial and Mass Murder: Theory, Research and Policy; Canadian Scholar's Press: Toronto, ON, Canada, 1996.

8. Skrapec, C. Phenomenology and serial murder: Asking different questions. Homicide Stud. 2001, 5, 46-63. [CrossRef]

9. Skrapec, C. Defining serial murder: A call for a return to the original Lustmörd. J. Police Crim. Psychol. 2001, 16, 10-24. [CrossRef]

10. Diaz, J.D. Killing as an initiator of self-change: A symbolic interactionist comparison of the etiology of Dennis Nilsen and Jeffrey Dahmer. Internet J. Criminol. 2006. Available online: http://www. internetjournalofcriminology.com (accessed on 20 March 2012). 
11. Holmes, S.T.; Tewksbury, R.; Holmes, R.M. Fractured identity syndrome: A new theory of serial murder. J. Contemp. Crim. Just. 1999, 15, 262-272. [CrossRef]

12. James, V.; Gossett, J. Of monsters and men: Exploring serial murderers' discourses of neutralization. Deviant Behav. 2018, 39, 1120-1139. [CrossRef]

13. Weist, J.B. Creating Cultural Monsters: Serial Murder in America; CRC Press: Boca Raton, FL, USA, 2011.

14. Force, W.R. The code of Harry: Performing normativity in Dexter. Crime Media Cult. 2010, 6, 329-345. [CrossRef]

15. Castle, T.; Hensley, C. Serial killers with military experience: Applying learning theory to serial murder. Int. J. Offender Ther. 2002, 46, 453-465. [CrossRef]

16. Silvio, H.; McCloskey, K.; Ramos-Grenier, J. Theoretical consideration of female sexual predator serial killers in the United States. J. Crim. Just. 2006, 34, 251-259. [CrossRef]

17. Yaksic, E. Addressing the challenges and limitations of utilizing data to study serial homicide. Crim. Psychol. Rev. 2015, 1, 108-134. [CrossRef]

18. Egger, S.A. The Serial Killers Among Us: An Examination of Serial Murder and Its Investigation; Prentice Hall: Upper Saddle River, NJ, USA, 1998.

19. Egger, S.A. The Need to Kill: Inside the World of the Serial Killer; Prentice Hall: Upper Saddle River, NJ, USA, 2003.

20. Farrell, A.L.; Keppel, R.D.; Titterington, V. Lethal ladies: Revisiting what we know about female serial murderers. Homicide Stud. 2011, 15, 228-252. [CrossRef]

21. Haggerty, K.D. Modern serial killers. Crime Media Cult. 2009, 5, 168-187. [CrossRef]

22. Hickey, E. Serial Murderers and Their Victims, 6th ed.; Wadsworth Cengage Publishing: Belmont, CA, USA, 2013.

23. Keeney, B.T.; Heide, K.M. Gender differences in serial murderers: A preliminary analysis. J. Interpers. Viol. 1994, 9, 383-398. [CrossRef]

24. Keeney, B.T.; Heide, K.M. Serial murder: A more accurate and inclusive definition. Int. J. Offender Ther. 1995, 39, 299-306.

25. Petee, T.; Jarvis, J. Analyzing violent serial offending: Guest editor's introduction. Homicide Stud. 2000, 4, 211-218. [CrossRef]

26. Thompson, J.; Ricard, S. Women's role in serial killing teams: Reconstructing a radical feminist perspective. Crit. Criminol. 2009, 17, 261-275. [CrossRef]

27. Vronsky, P. Serial Killers: The Method and Madness of Monsters; Berkeley Books: New York, NY, USA, 2004.

28. Hewitt, J.P. Self and Society: A Symbolic Interactionist Social Psychology, 7th ed.; Allyn and Bacon: Boston, MA, USA, 1997.

29. Hochstetler, A.; Copes, H.; Williams, J.P. 'That's not who I am': How offenders commit violent acts and reject authentically violent selves. Just. Q. 2010, 27, 492-516. [CrossRef]

30. Maruna, S.; Copes, H. What have we learned from five decades of neutralization research? Crime Just. A Rev. Res. 2005, 32, 221-320. [CrossRef]

31. Mills, C.W. Situated actions and vocabularies of motive. Am. Sociol. Rev. 1940, 5, 904-913. [CrossRef]

32. Pogrebin, M.; Stretesky, P.B.; Unnithan, P.; Venor, G. Retrospective accounts of violent events by gun offenders. Deviant Behav. 2006, 27, 479-501. [CrossRef]

33. Presser, L. Stories of Violent Men: Discursive Construction of Offender Identities. Ph.D. Dissertation, University of Cincinnati, Cincinnati, OH, USA, 2002.

34. Presser, L. Remorse and neutralization among violent male offenders. Just. Q. 2003, 20, 801-823. [CrossRef]

35. Presser, L. Violent offenders, moral selves: Constructing identities and accounts in the research interview. Soc. Probl. 2004, 51, 82-101. [CrossRef]

36. Presser, L. Getting on top through mass murder: Narrative, metaphor, and violence. Crime Media Cult. 2012, 8, 3-21. [CrossRef]

37. Rhodes, R. Why They Kill; Vintage Books: New York, NY, USA, 1999.

38. Sandberg, S. What can 'lies' tell us about life? Notes towards a framework of narrative criminology. J. Crim. Just. Edu. 2010, 21, 447-465. [CrossRef]

39. Scott, M.; Lyman, S. Accounts. Am. Sociol. Rev. 1968, 33, 46-62. [CrossRef] [PubMed]

40. Cooley, C.H. Human Nature and the Social Order; Charles Scribner's Sons: New York, NY, USA, 1902.

41. Goffman, E. Stigma: Notes on the Management of Spoiled Identity; Prentice Hall: Englewood Cliffs, NJ, USA, 1963. 
42. Bartels, R.; Parsons, C. The social construction of a serial killer. Fem. Psychol. 2009, 19, 267-280. [CrossRef]

43. Levin, J.; Fox, J.A. Normalcy in behavioral characteristics of the sadistic serial killer. In Serial Murder and the Psychology of Violent Crimes; Kocsis, R., Ed.; Humana Press Inc.: Totowa, NJ, USA, 2007; pp. 3-14.

44. Goffman, E. The Presentation of Self in Everyday Life; Anchor Books, Doubleday: New York, NY, USA, 1959.

45. Sykes, G.; Matza, D. Techniques of neutralization: A theory of delinquency. Am. Sociol. Rev. 1957, 22, 664-670. [CrossRef]

46. Copes, H.; Williams, J.P. Techniques of affirmation: Deviant behavior, moral commitment, and subcultural identity. Deviant Behav. 2007, 28, 247-272. [CrossRef]

47. Christensen, T. Presumed guilty: Constructing deviance and deviants through techniques of neutralization. Deviant Behav. 2010, 31, 552-577. [CrossRef]

48. Copes, H. Societal attachments, offending frequency, and techniques of neutralization. Deviant Behav. 2003, 24, 101-127. [CrossRef]

49. Gailey, J.A.; Prohaska, A. 'Knocking off a fat girl': An exploration of hogging, male sexuality, and neutralizations. Deviant Behav. 2006, 27, 31-49. [CrossRef]

50. Green, G.; South, N.; Smith, R. 'They say that you are a danger but you are not': Representations and construction of the moral self in narratives of dangerous individuals. Deviant Behav. 2006, 27, 299-328. [CrossRef]

51. McCarthy, J.G.; Stewart, A.L. Neutralization as a process of graduated desensitization: Moral values of offenders. Int. J. Offender Ther. 1998, 42, 278-290. [CrossRef]

52. Topalli, V. When being good is bad: An expansion of neutralization theory. Criminology 2005, 43, 797-835. [CrossRef]

53. Topalli, V. The seductive nature of autotelic crime: How neutralization theory serves as a boundary condition for understanding hardcore street offending. Sociol. Inq. 2006, 76, 475-501. [CrossRef]

54. Presser, L. The narrative of offenders. Theor. Criminol. 2009, 13, 177-200. [CrossRef]

55. Brookman, F.; Copes, H.; Hochstetler, A. Street code as formula stories: How inmates recount violence. J. Contemp. Ethnogr. 2011, 40, 397-424. [CrossRef]

56. Youngs, D.; Canter, D.V. Offenders' crime narratives as revealed by the narrative roles questionnaire. Int. J. Offender Ther. 2013, 57, 289-311. [CrossRef] [PubMed]

57. Shoemaker, D.J. Theories of Delinquency: An Examination of Explanations of Delinquent Behavior, 5th ed.; Oxford Press: New York, NY, USA, 2005.

58. Ugelvik, T. The rapist and the proper criminal: The exclusion of immoral others as narrative work on the self. In Narrative Criminology: Understanding Stories of Crime; Presser, L., Sandberg, S., Eds.; New York University Press: New York, NY, USA, 2015; pp. 23-41.

59. Miller, J.; Carbone-Lopez, K.; Gunderman, M.V. Gendered narratives of self, addiction, and recovery among women methamphetamine users. In Narrative Criminology: Understanding Stories of Crime; Presser, L., Sandberg, S., Eds.; New York University Press: New York, NY, USA, 2015; pp. 69-95.

60. Dodder, R.A.; Hughes, S.P. Neutralization of drinking behavior. Deviant Behav. 1993, 14, 65-79. [CrossRef]

61. McCabe, D.L. The influence of situational ethics on cheating among college students. Sociol. Inq. 1992, 62, 365-374. [CrossRef]

62. Vasquez, A.; Vieraitis, L.M. 'It's just paint': Street taggers' use of neutralization techniques. Deviant Behav. 2016, 37, 1179-1195. [CrossRef]

63. Shoenberger, N.; Heckert, A.; Heckert, D. Techniques of neutralization theory and positive deviance. Deviant Behav. 2012, 33, 774-791. [CrossRef]

64. Benson, M. Denying the guilty mind: Accounting for involvement in a white collar crime. Criminology 1985, 23, 583-607. [CrossRef]

65. Leasure, P. Neutralizations in retail banking: A qualitative analysis. Deviant Behav. 2017, 38, 448-460. [CrossRef]

66. Piquero, N.L.; Tibbetts, S.G.; Blankenship, M.B. Examining the role of differential association and techniques of neutralization in exploring corporate crime. Deviant Behav. 2005, 26, 159-188. [CrossRef]

67. Dutton, D.G. Wife assaulter's explanations for assault: The neutralization of self-punishment. Can. J. Behav. Sci. 1986, 18, 381-390. [CrossRef]

68. Deshotels, T.H.; Forsyth, C.J.; New, B.; Fulmer, J. For HE tells me so: Techniques of neutralization applied to christian domestic discipline. Deviant Behav. 2018, 1-20. [CrossRef] 
69. Wood, J.T. Monsters and victims: Male felons' accounts of intimate partner violence. J. Soc. Pers. Relat. 2004, 21, 555-576. [CrossRef]

70. Murphy, E. Anticipatory accounts. Symb. Interact. 2004, 27, 129-154. [CrossRef]

71. Liddick, D. Techniques of neutralization and animal rights activists. Deviant Behav. 2013, 34, 618-634. [CrossRef]

72. Boyle, K.M.; Walker, L.S. The neutralization and denial of sexual violence in college party subcultures. Deviant Behav. 2016, 37, 1392-1410. [CrossRef]

73. Hale, R.L. Motives of reward among men who rape. In Sexual Deviance: A Reader; Hensley, C., Tewksbury, R., Eds.; Lynn Rienner Publishers: Boulder, CO, USA, 2003; pp. 91-103.

74. Lea, S.; Auburn, T. The social construction of rape in the talk of a convicted rapist. Fem. Psychol. 2001, 11, 11-33. [CrossRef]

75. Scully, D.; Marolla, J. Convicted rapists' vocabulary of motive: Excuses and justifications. Soc. Probl. 1984, 31, 530-544. [CrossRef]

76. DeYoung, M. The world according to NAMBLA: Accounting for deviance. J. Sociol. Soc. Welf. 1989, 16, 111-126.

77. Durkin, K.; Bryant, C. Propagandizing pederasty: A thematic analysis of the online exculpatory accounts of unrepentant pedophiles. Deviant Behav. 1999, 20, 103-127. [CrossRef]

78. Maratea, R.J. Screwing the pooch: Legitimizing accounts in a zoophilia on-line community. Deviant Behav. 2011, 32, 918-943. [CrossRef]

79. Kooistra, P.G.; Mahoney, J.S. The road to hell: Neutralization of killing in war. Deviant Behav. 2016, 37, 761-783. [CrossRef]

80. Dietz, M.L. Killing sequentially: Expanding the parameters of the conceptualization of serial and mass killers. In Serial E Mass Murder: Theory, Research and Policy; O'Reilly-Fleming, T., Ed.; Canadian Scholar's Press: Toronto, ON, Canada, 1996; pp. 109-122.

81. Rule, A. The Stranger Beside Me: The Shocking Inside Story of Serial Killer Ted Bundy; Pocket Books: New York, NY, USA, 2009.

82. Michaud, S.G.; Aynesworth, H. Ted Bundy: Conversations with a Killer; Signet, Penguin Books, Inc.: New York, NY, USA, 1989.

83. Keppel, R.D. The Riverman: Ted Bundy and I Hunt for the Green River Killer; Pocket Books: New York, NY, USA, 1995.

84. Ressler, R.K.; Shachtman, T. I Have Lived in the Monster: Inside the Minds of the World's Most Notorious Serial Killers; St. Martin's Paperbacks: New York, NY, USA, 1997.

85. Davis, D. The Milwaukee Murders: Nightmare in Apartment 213: The True Story; St. Martin's Paperbacks: New York, NY, USA, 1991.

86. Ressler, R.K.; Shachtman, T. Whoever Fights Monsters; St. Martin's Paperbacks: New York, NY, USA, 1991.

87. Amirante, S.L.; Broderick, D. John Wayne Gacy: Defending a Monster; Skyhorse Publishing: New York, NY, USA, 2012.

88. Cahill, T. Buried Dreams: Inside the Mind of John Wayne Gacy; Bantam Books: New York, NY, USA, 1986.

89. Conversations with a Killer: The Ted Bundy Tapes. Netflix. Available online: http://www.netflix.com (accessed on 20 March 2019).

90. Ted Bundy's Last Interview. Youtube. Available online: https://www.youtube.com/watch?v=Vlk_sRU49TI (accessed on 10 January 2019).

91. Jeffrey Dahmer Original Stone Phillips Interview. Youtube. Available online: https://www.youtube.com/ watch?v=4MK9gIxbxrk (accessed on 10 January 2019).

92. Berry-Dee, C. Serial Killers: Up Close and Personal; Ulysses Press: Berkeley, CA, USA, 2007.

(C) 2019 by the author. Licensee MDPI, Basel, Switzerland. This article is an open access article distributed under the terms and conditions of the Creative Commons Attribution (CC BY) license (http://creativecommons.org/licenses/by/4.0/). 